\title{
The lower medical corridor
}

\author{
JAMES S STEWART
}

Before 1965 medical registrars and research fellows at Hammersmith were introduced to clinical science in a prefabricated hut known as the Lower Medical Corridor. This long, narrow, unattractive, single storey building was squeezed in between two threestorey blocks, one housing the medical wards, the other the hospital routine laboratories. It provided the only research space for gastroenterology, cardiology, and respiratory physiology. Each unit had a laboratory of $300 \mathrm{sq}$ feet and two small offices. Chris Booth's office was first on the right. I can still remember clearly, across nearly 30 years, his first words to me, 'Don't think that I'm a gastroenterologist. I start at the pylorus and I finish at the ileocaecal valve'.

The office was the scene of a monthly 'audit' meeting. Members of the Gastroenterology Unit would review all patients admitted during the preceding month and discuss what had been learned and what could have been learned from their problems perhaps not quite what the DHSS has in mind for medical audit in the 1990's. CCB would sit in his armchair and the rest of us would perch around on any convenient piece of furniture, or on the floor. On one such occasion, the disposition of figures composing the scene chanced to be remarkably symmetrical. The door opened and David Mollin appeared: "What a perfect picture of the Victorian family seated around the father figure!' Certainly the physical closeness engendered by lack of space gave a strong family feeling to all our endeavours.

Chris Booth's introduction to the Lower Medical Corridor came in 1959 when he succeeded Sheila Sherlock who had left for the chair of medicine at the Royal Free, taking Tony Dawson and others with her. Roger Williams, who had been working on asbestosis with Guy Scadding, Charles Fletcher, and Philip Hugh Jones, joined the exodus to Gray's Inn Road. Alan Read became senior registrar in gastroenterology on his way to the chair at Bristol and David Kerr became registrar before going on to a distinguished career in Renal Medicine, the chair of medicine in Newcastle, and now Dean at the RPMS. The two adjacent ground floor wards provided beds not only for gastroenterology but also for endocrinology and rheumatology. The wards were impossibly cramped yet provided the physical base for prolonged clinical discussions. For each patient there would be the usual presentation of symptoms and signs but the ensuing discussions often strayed far from the usual interpretation of disease processes offered by standard textbooks. Whenever a complete assessment was impossible there was a predictable final comment from Chris, 'Well, continue to record the facts'.

Patients with gastric or small intestinal pathology were sometimes transferred from the general wards to the Metabolic Unit. Such patients were often malnourished in a way rarely seen today. In the Metabolic Unit the term 'pressure on beds' was never heard and one metabolic balance study followed another. The efforts of the ward staff - and the forebearance of the patients - rarely went unrewarded. And in this way we learned the management of hypomagnesaemia,' protein malnutrition, ${ }^{2}$ poor response coeliac disease, ${ }^{3}$ short bowel syndrome, ${ }^{+}$and many other chronic intestinal disorders.

Some problems could be more dramatic. One Sunday morning a young man was admitted with a haemoglobin of $3 \mathrm{~g} / 100 \mathrm{ml}$, gross macrocytosis and a marrow which was so megaloblastic that at first it was thought to indicate erythroleukaemia. He had failed 'Elsewhere' to respond to $\mathrm{B}_{12}$ and so folate deficiency was a strong possibility. In those days folate metabolism was ill-understood. Any patient with folate or $\mathrm{B}_{12}$ deficiency was 'for discussion'. Two telephone calls and an hour later Chris Booth, David Mollin, and junior staff were locked in such a discussion. There was no ethics committee to consult. The patient was young, the diagnosis uncertain. It was agreed to give him just $0.1 \mathrm{mg}$ pteroylmonoglutamate per day by mouth and to observe closely for any sign of deterioration. The anxiously awaited rise in reticulocytes duly followed and the patient later became fit for jejunal biopsy which showed the flat mucosa of coeliac disease. The addition of ferrous sulphate completed the haematological response. On looking back at that episode one remembers with sadness the death of David Mollin in January of this year, a particularly sore loss for Chris Booth after so long and so close a friendship.

The heart of the Unit lay in the Lower Medical Corridor. It was, in the words of John Vallance Owen, 'a most remarkable place'. In the mid-50's, John McMichael, John Vallance Owen, and Winnic (Miss E J Wernli) seemed to take it in turns to be into work first thing in the morning. Winnie was general 
factotum. She kept the place clean and tidy and when necessary, provided technical help. One morning before 8 o'clock she said to John Vallance Owen, 'I don't know about the work, sir, but you certainly keep the hours. 'The work' was some of the earliest on measuring insulin in blood. In gastroenterology Winnie deserves to be remembered for helping Margot Shiner direct the gastric biopsy tube through the pylorus and so obtain the first per oral biopsies of the small intestine in Britain. Winnie was there in 1959 when Chris arrived from his secondment to the Department of Haematology and she was still there when Moran Campbell, in the adjacent laboratory was stripped to the waist furiously pedalling his ergometer bicycle attached to a Heath Robinson array of machinery.

The gastroenterology laboratory was cramped beyond belief. On the left inside the door the mysteries of coeliac disease were explored by Ted Holmes and later by myself. In the far left hand corner was Hermon Dowling, now Professor of Gastroenterology at Guy's. He arrived with a strong Northern Irish accent and a clear capacity for hard work. It was not long before he was producing a stream of highly original studies on intestinal adaptation. The next section of bench was for animal work and was variously occupied by Hermon Dowling, Victor Hoffbrand (now Professor of Haematology at the Royal Free) and Gilbert Thompson. Victor's experiments with Chris Booth were a special cause for excitement as they prepared everted sacs of small intestine in an attempt to elucidate the problems of folate absorption. Victor soon returned to Haematology which gave more room to Gil Thompson (now Director of the MRC Lipoprotein Team) who was struggling to purify the $3 \mathrm{H}$-labelled vitamin D3 from the calciferol which he had sent to Amersham for random labelling with tritium. Gilbert was the first person to study the absorption of vitamin $D$ in $\operatorname{man}^{n}$ and in the process, he taught himself sterol chemistry, an achievement which ultimately took him to his present position. Near the door of the laboratory on the right hand side was Soad Tabaqchali working on the effects of bacteria in the stagnant loop syndrome.? This soon led to the demonstration of deconjugated bile salts both in the gut and in the blood of affected patients and then to some fascinating observations on the bacteriology of the gut in association with Sherry Gorbach (visiting fellow from the USA). Soad became Lady Booth but firmly maintained her independence in research, and later was to become Professor of Medical Microbiology at St Bartholomew's. Somewhere along the centre table would be found Mike Brain (now Professor of Haematology at McMaster University) making seminal observations on microangiopathic haemolytic anaemia, and Graham Neale working on postsurgical nutritional disturbances which took him to the Metabolic Unit for long hours.

In the centre of all this was Janet Heath, a nurse turned technician who was appointed at the very beginning of the Booth era. Janet worked with Chris for 17 years. Now a Nurse Manager, she recalls her interview for the job as medical technician for which she had no formal qualifications. For much of the interview, $\mathrm{CCB}$ was crouched on the floor of his office drawing charts for the next meeting of the Medical Research Society. At that time research workers drew their own charts for papers and demonstrations to be given to the Medical Research Society or the British Society of Gastroenterology. The labour involved was as nothing compared with that of rehearsals. If a research fellow didn't know how to give a paper by the time he or she left the Unit it was not the fault of the senior staff. Time and again, just when one thought all was well with the current rehearsal, David Mollin would appear to remark, 'There's only one thing wrong with this paper: it's back to front'. The text was turned round, the first and last slides interchanged and new slides drawn up often as not the day before the meeting. The last rehearsal would be in the hotel room. Nevertheless, at the end of what had to be the final rehearsal, CCB would assure the thoroughly battered research fellow 'You show them ... It'll be the best paper of the meeting'. And sometimes it was - or so it seemed to us.

One of the most remarkable and enjoyable things about working with Chris was the loyalty he engendered within the Unit and the mutual support in crises large and small. Out of what at times seemed to be a chaos and confusion, there appeared a stream of interesting and at times important papers stemming from the original work of Booth and Mollin in 1959 on the site of $B_{12}$ absorption." In 1966, when Dr Booth became Professor Booth and Director of the Department of Medicine, the gastroenterology laboratory moved to more spacious accommodation. This gave room for research fellows from Australia, Canada, New Zealand, South Africa, the USA, India, Germany, Greece, Norway, and Poland as well as from the United Kingdom and the Irish Republic. Research became much more sophisticated and Chris became less directly involved although he always remained enthusiastically 'fascinated' and most supportive. But it was especially the years when the medical research laboratories were in the Lower Medical Corridor to which the historian Noel Poynter referred when he described Hammersmith as 'The most advanced and successful medical school in the British Commonwealth ... an example of what can be achieved when the restric- 
tions imposed by tradition and vested interests are loosened." "Some of the observations of those clinicians who worked with Chris in the Lower Medical Corridor now seem 'steam age' but the spirit of scientific enquiry he engendered has diffused far and wide as evidenced by the contributions to this Festschrift.

Dept of Medicine, West Middlesex University Hospital, Isleworth, Middlesex

\section{References}

1 Booth CC. Babouris N. Hanna S, Macintyre I. Incidence of hypomagnesacmia in intestinal malabsorption. Br Med J 1963: 2: 141-4.

2 Nealc G. Antcliff AC, Welbourn RB, Mollin DL, Booth CC. Protein malnutrition after partial gastrectomy. QJ Med 1969; 36: 469-94.
3 Neale G. A case of adult cocliac discase resistant to treatment. Br Med J 1968; 2: 678-84.

4 Booth CC, McIntyre I, Mollin DL. Nutritional problems associated with extensive lesions in the distal small intestine in man. $Q J$ Med 1964; 33: 401-20.

5 Shiner M. Duodenal biopsy. Lancet 1956; i: 17-19; 85.

6 Thompson GR, Lewis B, Booth CC. Absorption of vitamin $\mathrm{D}-3 \mathrm{H}$ in control subjects and patients with intestinal malabsorption. J Clin Invest 1970; 45: 94-102.

7 Tabaqchali S. The pathophysiological role of small intestinal bacterial flora. Scand J Gastroenterol 1970: 6 [suppl]: 139-63.

8 Brain MC, Hourihane DO. Microangiopathic haemolytic anaemia: The occurrence of haemolysis in experimentally produced vascular disease. $\mathrm{Br} J$ Haematol 1967: 13: 135-42.

9 Booth CC. Mollin DM. The site of absorption of vitamin B12 in man. Lancet 1959; i: 18-21.

10 Poynter FNL. Medical education in England since 1600. In: O'Malley CD. ed. The history of medical education. Los Angeles: University of California Press, 1970: 23550. 